\title{
Comparative immunohistochemical analysis of Beclin-1 \& MDM-2 in benign \& malignant ameloblastomas
}

MA Elbarrawy

From 30th Annual Meeting and Associated Programs of the Society for Immunotherapy of Cancer (SITC 2015)

National Harbor, MD, USA. 4-8 November 2015

\section{Background}

Ameloblastoma is the most frequently encountered neoplasm arising from the odontogenic epithelium. Beclin-1 protein plays a critical role in autophagy as a tumor suppressor gene. Whereas, the Murine Double Minute 2 (MDM-2) is a cellular proto-oncogene capable, if amplified, of causing tumor-genesis. The expression \& prognostic significance of both genes are largely unexplored, yet, in this neoplasia. Therefore, the present investigation aimed to assess their possible biological role in ameloblastomas.

\section{Methods}

This study was done among 35 studied cases: 29 cases of benign ameloblastomas, and 6 cases of ameloblastic carcinomas. Labeled Streptavidin Biotin (LSAB + Dako) immunohistochemical method, utilizing monoclonal antibodies for Beclin-1 \& MDM-2 genes, was used.

\section{Results}

Most of the benign ameloblastomas, 25 out of 29 cases (86\%), showed intense total cell positivity for the Beclin-1, while, the ameloblastic carcinomas revealed mild (3 out of 6 cases, 50\%) to negative expression (3 cases: $50 \%$ ). Inversely, the MDM-2 oncoprotein demonstrated intense brown total cell reactivity in amelobastic carcinoma (5 out of 6 cases, $83 \%$ positivity) \& loss of the reaction (21 cases: $72 \%$ ) to mild brown stain (8 cases:28\%) in benign ameloblastoma. These findings were statistically significant.

\section{Conclusion}

Based from these findings, one could conclude that, MDM-2 could be a specific marker to identify the

Alexandria University Egypt, Alexandria, Egypt proliferative activity, tumor aggressiveness \& directly proportional with the degree of malignancy. In contrast, the high Beclin-1 expression could be a good indicator of prognosis in ameloblastomas. Hence, an overall comparison, both studied genes may be very promising molecular prognostic biomarkers.

Published: 4 November 2015

doi:10.1186/2051-1426-3-S2-P101

Cite this article as: Elbarrawy: Comparative immunohistochemical analysis of Beclin-1 \& MDM-2 in benign \& malignant ameloblastomas. Journal for ImmunoTherapy of Cancer 2015 3(Suppl 2):P101.
Submit your next manuscript to BioMed Central and take full advantage of:

- Convenient online submission

- Thorough peer review

- No space constraints or color figure charges

- Immediate publication on acceptance

- Inclusion in PubMed, CAS, Scopus and Google Scholar

- Research which is freely available for redistribution
() Biomed Central 